\title{
Research on Relationship between Chinese Traditional Vocal Music and City Marketing
}

\author{
Shengnan Liu \\ Lingnan Normal University \\ Zhanjiang, China
}

\begin{abstract}
Today, the economy is globalized, both opportunities and challenges exist, and the competition among cities is also accelerated sharply. In order to meet the quick needs change of residents, tourists and investors and to improve their consume attitudes, all cities must adopt the top-level design of difference and strategies to increase their competitiveness, and further to win the consumption of urban residents, tourists and investors. This study made verification of the relationship among Chinese national vocal music as characteristic of city marketing, the psychological and physical attitude and action intentions of urban residents, travelers and investors. Cities can choose the Chinese National Vocal Music in accordance with their own image and the city image propaganda works with Chinese national vocal music as the carrier is undoubtedly the key to city marketing.
\end{abstract}

Keywords-Chinese national vocal music; city marketing; psychological attitude; physical attitude

\section{INTRODUCTION}

Since the 1980s, the world-wide urbanization has made separation of powers and multi central governance become popular. Cities begin to participate in cross-border global economy. The situation that opportunities and challenges coexist and limitation of resources decide the form of competitive relation between cities. [1] In order to meet the quick change of requirements of residents, travelers and investors and consumption concept that improves continuously, cities need to adopt different and strategic top-level design to increase urban competitiveness, in order to win over consumption of urban residents, travelers and investors. People's consciousness on decision of product or service starts from sensibility. Music justly can convey and express human emotion and influence people's behavior in subconscious. Music is a kind of spirit culture phenomenon that has broad social impact. Its creation, performance and activities of appreciation will produce certain social effects. Good music can purify people's heart, cultivate people's taste, enlighten people's wisdom as well as encourage people's spirit. But those vulgar music will paralyze people's emotion, corrode people's thinking, wear down volition of people even have bad influence on general mood of society. Chinese traditional vocal music is a colorful wonderful flower in the field of vocal music art. It is scientific, national, artistic and epochal, influences theme of the new era, and continuously innovates and develops in the communication with music culture in various countries in the world. Besides, people of all countries pay extensive attention to and love it. [2] So Chinese traditional vocal music has positive influence on city marketing.

City music refers to the situation that in city, people use voice as the carrier to express their spirit, thought and emotion and carry out in organized, professional and operational way. Business operation is an important characteristic. It promotes ideology, social behavior and consumption pattern of people in city life. It is a kind of cultural phenomenon that inherits and develops human civilization. [3] A case is London Docklands Development Corporation (LDDC for short). It organizes a large number of local workers and researchers, refers to theory of local marketing to successfully rebuild local image of Docklands and changes the local image of Docklands that declines increasingly. [4] The current situation in China is that most cities in China adopt Chinese traditional vocal music to make city videos. National music academic circles shall face the objective circumstances, call on people to look into the city and vigorously carry out the research on urban ethnomusicology. [5]

\section{THEORETICAL BACKGROUND}

$\mathrm{Xu}$ Yuzhong discusses the possibility of combination of music and economy in the article of "Thinking on Music Economic Activity Research". Zhou Honglei discusses in the article of "the Call of the Times-Music City Marketing" about problems such as how all kinds of music continue to survive in the environment of market economy, how to use law of market economy to promote the development of music. As a kind of concept put forward in recent years, in fact, city marketing is a new division of traditional marketing area. Therefore, city marketing is a regional marketing process on the basis of regional or urban planning. The nine success factors of city marketing includes planning group, vision and strategic analysis, place identity and place image, publicprivate partnerships, political unity, global marketplace, local development, process coincidences and leadership. [6] The school of city image in city marketing advocates to understand city marketing as the process to form and spread city image and thinks that city image has very important influence on purchasers of city products; city marketing shall start from the design of local image. As a kind of flexible cultural element, music plays a key role in city marketing: It meets the requirements of consumers, increases the charm of city and enhances the competitiveness of city. Many researches show that good environment itself cannot bring more value for the 
city. It will bring value through meeting requirements of residents, travelers and investors. But in domestic and foreign theoretical researches, they all pay attention to researching basic theory of city marketing. In the aspect of Chinese traditional vocal music, they only attach importance to singing method, techniques and development. In the field of city marketing, at present, there isn't research on relationship between Chinese traditional vocal music and city marketing. Meanwhile, there isn't research on how Chinese traditional vocal music meets requirements of residents, travelers and investors in city marketing. In the field of marketing, merchants want to grasp instinctive mental state model of consumers and change irregular mental state of consumers into regular mental state. Equally, extend it to city marketing, change irregular mental state of residents, travelers and investors into regular mental state to build the model of requirements of residents, travelers and investors, which help to better design city image and attract consumption and investment.

Music can convey and express people's emotion. It is different according to different purposes of use. If music has no relationship with culture, civilization and environment, then the fundamental functions of music include emotional expressions, aesthetic pleasure, entertainment, communication, performance, body response, social rules and regulations, religious consciousness, continuity of culture and social balance, etc. [6] Therefore, multifarious techniques of expression of music can achieve the effect of communication very well. As means of communication, according to types or performance of music, music has different explanation in different cultural circles. For example, when using Chinese traditional vocal music as the means of communication, Chinese traditional vocal music belongs to China and has Chinese characteristics. The meaning of "Chinese characteristics" refers to cultural psychology, character and temperament features that 56 nationalities in China have, namely the characteristics of Chinese nation. [7] Its diversified techniques of expression can represent characteristics of 56 nationalities. Therefore, it can achieve the effect of communication very well. No matter Chinese traditional vocal music has what kind of meaning or symbolism and although it has different understanding, in different situations or scenes, it is true that Chinese traditional vocal music is widely used as a kind of function of city marketing.

Chinese traditional vocal music is a very important element in atmosphere of city marketing and has advantages such as simple control and economic cost. Residents, travelers and investors will cause different impression on cities according to types of Chinese traditional vocal music and perception of city style.

\section{RESEARCH MODEL AND HYPOTHESIS “FIG. 1"}

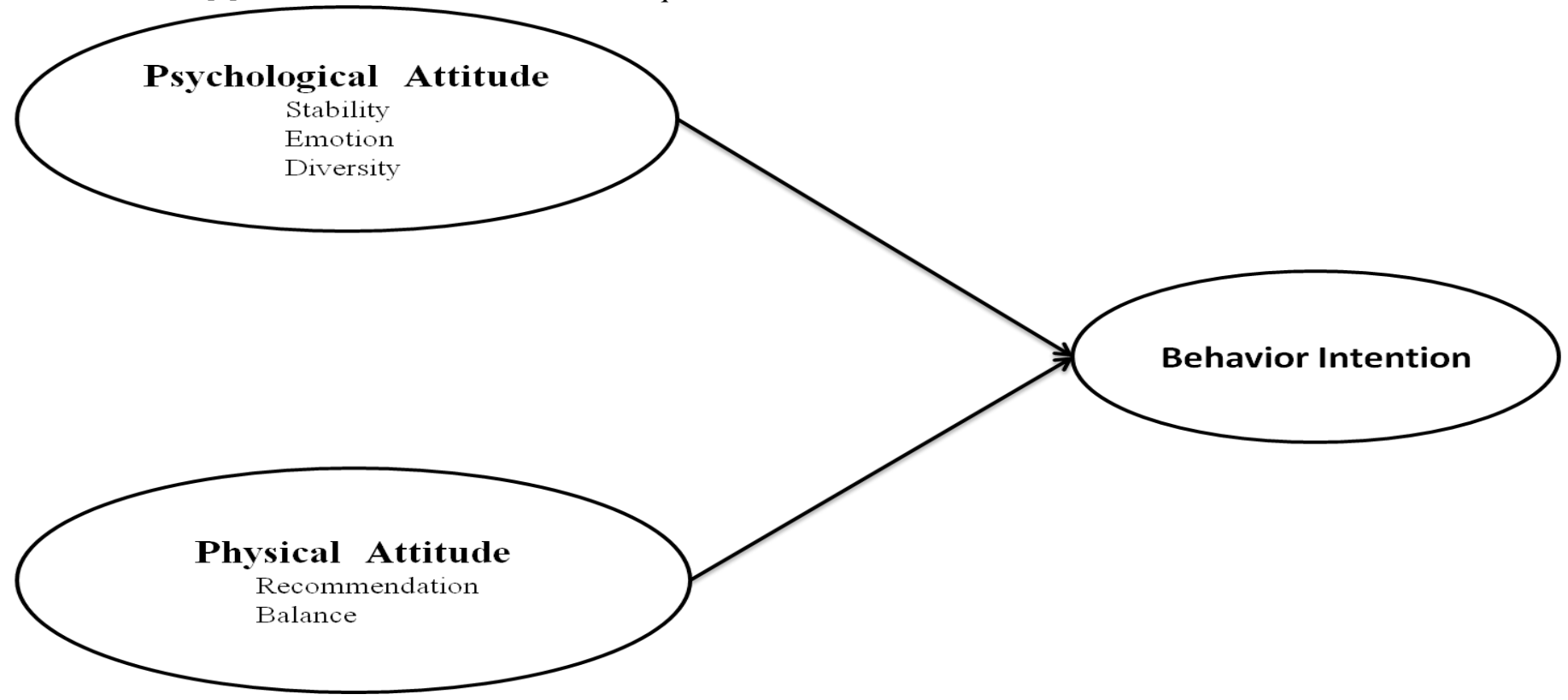

Fig. 1 Model and hypothesis

In fundamental research, music environment of the city has influence on changes of psychological or emotional state. According to fundamental research, traditional vocal music can make residents, travelers and investors feel pleasure, improve quality of service and increase cordial feeling, to improve competitiveness of city. Chinese traditional vocal music can cause changes of physical attitudes of residents, travelers and investors and induce them to consume or invest.
Research hypothesis 1: As psychological attitude factor of city marketing, Chinese traditional vocal music has influence of positive direction on behavior intention of residents, travelers and investors in city.

Hypothesis 1-1: As stability factor of city marketing, Chinese traditional vocal music has influence of positive direction on behavior intention of residents, travelers and investors in city. 
Hypothesis 1-2: As emotion factor of city marketing, Chinese traditional vocal music has influence of positive direction on behavior intention of residents, travelers and investors in city.

Hypothesis 1-3: As diversity factor of city marketing, Chinese traditional vocal music has influence of positive direction on behavior intention of residents, travelers and investors in city.

Research hypothesis 2: As physical attitude factor of city marketing, Chinese traditional vocal music has influence of positive direction on behavior intention of residents, travelers and investors in city.

Hypothesis 2-1: As recommendation factor of city marketing, Chinese traditional vocal music has influence of positive direction on behavior intention of residents, travelers and investors in city.

Hypothesis 2-2: As balance factor of city marketing, Chinese traditional vocal music has influence of positive direction on behavior intention of residents, travelers and investors in city.

\section{RESEARCH RESULTS}

\section{A. Composition of Sample}

The questionnaire is carried out randomly in department stores (world trade, international trade, city square and Wanxiang Square) in Zhanjiang city, Guangdong province in December 1, 2015. Issue 240 questionnaires in total, including 198 valid questionnaires. "Table I".

TABLE I. SAMPLE COMPOSITION RESUlTS

\begin{tabular}{|l|l|l|c|}
\hline \multicolumn{2}{|c|}{ Difference } & Frequency & Ratio \\
\hline \multirow{3}{*}{ Gender } & Male & 110 & 55.6 \\
\cline { 2 - 4 } & Female & 88 & 44.4 \\
\cline { 2 - 4 } & Total & 198 & 100.0 \\
\hline \multirow{4}{*}{ Age } & $10-20$ & 27 & 13.6 \\
\cline { 2 - 4 } & $20-30$ & 79 & 39.9 \\
\cline { 2 - 4 } & $30-40$ & 62 & 15.3 \\
\cline { 2 - 4 } & Over50 & 30 & 100.0 \\
\cline { 2 - 4 } & Total & 198 & \\
\cline { 2 - 4 } & & & \\
\hline
\end{tabular}

\section{B. Factor Analysis and Reliability Analysis}

Firstly, according to data on questionnaire, take Chinese traditional vocal music as psychological attitude of city marketing in city to do factor analysis and reliability analysis. Results of data analysis are shown in "Table II", "Table III" and "Table IV" Judge KMO value of accuracy of sample, it is 0.873 on psychological attitude, 0.979 on physical attitude and 0.899 on behavior intention. Therefore, it can judge that the sampled sample is appropriate. The Cranach's alpha value that represents reliability of them is higher than 0.6 . So it can judge that the research sample has very high level of reliability.
TABLE II. FACTOR ANALYSIS AND RELIABILITY ANALYSIS ON PSYCHOLOGICAL ATTITUDE

\begin{tabular}{|c|c|c|c|c|c|}
\hline $\begin{array}{l}\text { Name of } \\
\text { Factors }\end{array}$ & Item & $\begin{array}{l}\text { Factor } \\
\text { Storage }\end{array}$ & $\begin{array}{l}\text { Value } \\
\text { of } \alpha\end{array}$ & $\begin{array}{l}\text { Scatter } \\
\text { factor }\end{array}$ & $\begin{array}{l}\text { Reliability } \\
\text { Coefficient }\end{array}$ \\
\hline \multirow[t]{7}{*}{ Stability } & Q1 & 0.815 & \multirow[t]{7}{*}{3.787} & \multirow[t]{7}{*}{24.378} & \multirow[t]{7}{*}{0.878} \\
\hline & Q2 & 0.725 & & & \\
\hline & Q3 & 0.589 & & & \\
\hline & Q4 & 0.701 & & & \\
\hline & Q5 & 0.845 & & & \\
\hline & Q6 & 0.803 & & & \\
\hline & Q7 & 0.601 & & & \\
\hline \multirow[t]{5}{*}{ Emotion } & Q8 & 0.831 & \multirow[t]{5}{*}{3.391} & \multirow[t]{5}{*}{21.374} & \multirow[t]{5}{*}{0.816} \\
\hline & Q9 & 0.790 & & & \\
\hline & Q10 & 0.643 & & & \\
\hline & Q11 & 0.716 & & & \\
\hline & Q12 & 0.722 & & & \\
\hline \multirow[t]{3}{*}{ Diversity } & Q13 & 0.679 & \multirow[t]{3}{*}{1.695} & \multirow[t]{3}{*}{12.674} & \multirow[t]{3}{*}{0.847} \\
\hline & Q14 & 0.815 & & & \\
\hline & Q15 & 0.631 & & & \\
\hline & & & & $37 \%$ & \\
\hline
\end{tabular}

TABLE III. FACTOR ANALYSIS AND RELIABILITY ANALYSIS ON PHYSICAL ATTITUDE

\begin{tabular}{|l|l|l|l|l|l|}
\hline \multirow{3}{*}{$\begin{array}{l}\text { Recomme } \\
\text { ndation }\end{array}$} & Q16 & 0.831 & 2.294 & 25.938 & 0.836 \\
\cline { 2 - 3 } & Q17 & 0.826 & & & \\
\cline { 2 - 3 } & Q18 & 0.517 & & & \\
\cline { 2 - 3 } Balance & Q19 & 0.751 & & & \\
& Q20 & 0.775 & 2.315 & 20.392 & 0.882 \\
\cline { 2 - 3 } & Q21 & 0.892 & & & \\
\cline { 2 - 3 } & Q22 & 0.831 & & & \\
\hline \multicolumn{2}{|l|}{ KMO:0.979 df=69,p=000 Scatter factor=69.319\% } & \\
\hline
\end{tabular}

TABLE IV. FACTOR ANALYSIS AND RELIABILITY ANALYSIS ON BEHAVIOR INTENTION

\begin{tabular}{|l|l|l|l|l|l|}
\hline Behavior Intention & Q23 & 0.731 & \multirow{2}{*}{3.001} & $\begin{array}{l}60.86 \\
9\end{array}$ & 0.891 \\
\cline { 1 - 3 } & Q24 & 0.687 & & & \\
\cline { 1 - 3 } & Q25 & 0.895 & & & \\
\cline { 2 - 3 } & Q26 & 0.838 & & & \\
\cline { 2 - 3 } & Q27 & 0.796 & & & \\
\hline
\end{tabular}

KMO:0.899 $\mathrm{df}=25, \mathrm{p}=000$ Scatter factor $=64.258 \%$

\section{Hypothesis Testing}

Test research hypothesis 1: Do multiple regression analysis on Chinese traditional vocal music as psychological attitude factor of city marketing that influences behavior intention of residents, travelers and investors in city. The result is shown in "Table V". The Emotion 0.414 ( $\mathrm{t}=5.691, \mathrm{p}=0.000)$ and 
Diversity $0.218 （ \mathrm{t}=3.231, \mathrm{p}=0.001 ）$ of psychological attitude factor of Chinese traditional vocal music is meaningful and it has influence of positive direction on behavior intention of residents, travelers and investors in city. Therefore, hypothesis 1-2 and hypothesis 1-3 are valid. Hypothesis 1-1 is invalid.

TABLE V. INFLUENCE OF PSYCHOLOGICAL ATtITUdE ON BEHAVIOR INTENTION

\begin{tabular}{|l|l|l|l|l|l|}
\hline $\begin{array}{l}\text { Independent } \\
\text { Variable }\end{array}$ & $\mathrm{B}$ & $\mathrm{S} . \mathrm{E}$. & $\mathrm{Beta}$ & $\mathrm{t}$-value & $\mathrm{P}$ \\
\hline Stability & 0.056 & 0.069 & 0.049 & 0.782 & 0.507 \\
\hline Emotion & 0.358 & 0.077 & 0.414 & $5.691 * * *$ & 0.000 \\
\hline Diversity & 0.238 & 0.051 & 0.218 & $3.231 * * *$ & 0.001 \\
\hline \multicolumn{7}{|c|}{$\mathrm{R} 2=0.348$, Adjuster $\mathrm{R} 2=0.336, \mathrm{~F}=33.992 * * \mathrm{P}<0.05, * * * \mathrm{P}<0.01$} \\
\end{tabular}

Test research hypothesis 2: Do multiple regression analysis on Chinese traditional vocal music as physical attitude factor of city marketing that influences behavior intention of residents, travelers and investors in city. The result is shown in "Table VI". The Recommendation $0.317 \quad(\mathrm{t}=5.190, \mathrm{p}=0.000)$ and Balance $0.295 \quad(\mathrm{t}=3.121, \mathrm{p}=0.009)$ of physical attitude factor of Chinese traditional vocal music is meaningful and it has influence of positive direction on behavior intention of residents, travelers and investors in city. Therefore, hypothesis 2-1 and hypothesis 2-2 are valid.

TABLE VI. INFLUENCE OF PHYSICAL ATtITUde ON BEHAVIOR INTENTION

\begin{tabular}{|l|l|l|l|l|l|}
\hline $\begin{array}{l}\text { Dependent } \\
\text { Variable }\end{array}$ & $\mathrm{B}$ & $\mathrm{S} . \mathrm{E}$. & Beta & $\mathrm{t}$-value & $\mathrm{P}$ \\
\hline $\begin{array}{l}\text { recommend } \\
\text { ation }\end{array}$ & 0.328 & 0.069 & 0.317 & $5.190 * * *$ & 0.000 \\
\hline Balance & 0.298 & 0.087 & 0.295 & $3.121 * *$ & 0.009 \\
\hline \multicolumn{2}{|c|}{$\mathrm{R} 2=0.447$, Adjuster $\mathrm{R} 2=0.451, \mathrm{~F}=46.324 * * \mathrm{P}<0.05, * * * \mathrm{P}<0.01$} \\
\hline
\end{tabular}

\section{CONCLUSION}

This research tests relationships between Chinese traditional vocal music as characteristics of city marketing and psychological attitude, physical attitude and behavior intention of urban residents, travelers and investors. Through research, realize the importance of Chinese traditional vocal music as a way of city marketing. Cities can choose types of Chinese traditional vocal music that conforms to their images as means to strengthen competitiveness of cities and establish strategies of city marketing and gain advantage in fierce urban competitiveness. The following two conclusions can be got in the research.

Firstly, as a way of city marketing, Chinese traditional vocal music will influence the changes of psychological attitude of urban residents, travelers and investors. It defines degree of importance and cognition degree with stability; defines emotion that can help the atmosphere of purchase and decision making process of consciousness in city marketing; defines diversity of meaning in volume, pitch and differentiation of Chinese traditional vocal music. Stability is meaningless on statistical property. Emotion and diversity of psychological attitude of urban residents, travelers and investors are meaningful and have influence of positive direction on behavior intention of consumers. This is because today's society is full of materialism, the competition of sale promotion is fierce and service competition upgrades. People attach more importance to diversified consumption and stimulation pattern than emotion. The leader of the city can flexibly choose to use Chinese traditional vocal music as a kind of means of city marketing to make strategies of city marketing.

Secondly, it defines recommendation and balance of physical attitude. It has meaningful influence of positive direction on statistical property. Balanced music can bring urban residents, travelers and investors positive impression and influence their final behavior. As a kind of means of city marketing, Chinese traditional vocal music can control the state of urban residents, travelers and investors such as pleasure and exciting. The leader of the city can base on characteristics of urban residents, travelers and investors and basic information of the city to make strategies and choose Chinese traditional vocal music works that conform to strategies of city marketing.

In conclusion, Chinese traditional vocal music has profound influence on city marketing. In marketing, people often use music as marketing method to influence subconscious of consumers. Music can provide good consumption environment and atmosphere, help to improve sales volume and loyalty of customers. It is also feasible to extend this concept to city marketing. For example, traditional vocal music works with positive energy can influence subconscious of urban residents, travelers and investors and increase their positive cognition and attraction on city. Nowadays, with rapid development of cities, the competition between cities centers on hardware construction of cities and ignores spiritual construction of cities. If a city hasn't cultural deposits and spiritual construction, how it can attract high quality residents and investors. Therefore, no matter from the perspective of economy or society, there is no doubt that works that publicize city image and take Chinese traditional vocal music as the carrier are key points of city marketing. It is necessary and meaningful to discuss the relationship between Chinese traditional vocal music and city marketing and research on finding relationships between characteristics of Chinese traditional vocal music and behavior intention of urban residents, travelers and investors. It also plays a positive role in spread and development of Chinese traditional vocal music.

\section{REFERENCES}

[1] Wang Jinfu, Zhang Daohong, Cheng Aiwu. Research Summary on Foreign Theory of City Marketing [J], Urban Problems, 2006, 137(9): 84-88.

[2] Wang Shikui. Practical Teaching Materials of Chinese Traditional Vocal Music Singing [M], Culture and Art Publishing House, 2004.

[3] Luo Qin. Urban Music Culture and Industrialization of Music [J], Art of Music, 2003, (2).

[4] SUSAN BALL.London office development and marketing[ J] .Ekistics ,1996,(4). 
[5] Du Yaxiong. National Musicologist, Please Look into the City [J], Chinese Music, 2011, (1)

[6] Seppo K Rainisto ( 2003) . Success Factors of Place Marketing:A Study of Place Marketing Practices in Northern Europe and the United States. Doctoral Dissertation. Helsinki University of Technology, Institute of Strategy and International Business.

[7] Jin Tielin. Jin Tielin Art of Vocal Music Teaching [M], People's Music Publishing House, 2008 